\title{
Generation and characterization of human monoclonal single chain variable fragments (scFvs) against envelope third variable region (V3) of HIV-1 clade C
}

\author{
Rajesh Kumar ${ }^{1 \dagger}$, Raiees Andrabi ${ }^{1 \dagger}$, Ashutosh Tiwari ${ }^{1}$, Somi Sankaran Prakash ${ }^{1}$, Naveet Wig ${ }^{1}$, Durgashree Dutta ${ }^{1}$, \\ Anurag Sankhyan', Lubina Khan', Subrata Sinha², Kalpana Luthra ${ }^{1 *}$
}

From First International Science Symposium on HIV and Infectious Diseases (HIV SCIENCE 2012)

Chennai, India. 20-22 January 2012

\section{Background}

Production of human monoclonal antibodies with broad neutralizing activity is an essential part of HIV-1 prophylactic vaccine. Majority of the viruses infecting Indian patients belong to clade $\mathrm{C}$.

\section{Methods}

A phage library of 7000 clones was constructed from a drug naive HIV-1 clade $C$ infected Indian patient whose plasma exhibited high potential neutralizing potential against a panel of viruses and also displayed cross-reactive anti-V3 antibodies. PBMCs were isolated and EBV transformed. Cells (wells) producing anti-V3 antibodies were preselected with V3-CTB fusion protein and expanded. Total RNA was isolated and cDNA was constructed followed by $\mathrm{VH}$ and $\mathrm{VL}$ amplification. scFvs were constructed, cloned into phagemid vector and expressed in Escherichia coli. We assessed the expression of the scFvs by SDSPAGE and Western blotting. Specificity was examined by ELISA.

\section{Results}

A total of 30 clones were randomly selected after biopanning and checked for their binding to V3 peptides of clade $\mathrm{C}$ and $\mathrm{B}$. Ten clones showed binding in phage ELISA, 8 were cross-reactive to both the V3 peptides while the other 2 were specific to V3C. The clones did not show cross-reactivity against other unrelated peptides. The recombinant anti-V3 scFvs $(32 \mathrm{kD})$ were expressed and confirmed by SDS-PAGE and Western blotting. DNA fingerprinting analysis showed that 9 out of the 10 clones were distinct.

\section{Conclusion}

This is the first report on the generation of human antiV3 scFvs against HIV-1 clade C. Further assessment of the neutralization efficiency of these scFvs would reveal their potential for passive immunotherapy.

\section{Author details \\ ${ }^{1}$ All India Institute of Medical Sciences, New Delhi, India. ${ }^{2}$ Director, National} Brain Research Centre, Manesar, India.

Published: 4 May 2012

doi:10.1186/1471-2334-12-S1-P11

Cite this article as: Kumar et al:: Generation and characterization of human monoclonal single chain variable fragments (scFvs) against envelope third variable region (V3) of HIV-1 clade C. BMC Infectious Diseases 2012 12(Suppl 1):P11.

\footnotetext{
* Correspondence: kalpanaluthra@gmail.com

† Contributed equally

${ }^{1}$ All India Institute of Medical Sciences, New Delhi, India

Full list of author information is available at the end of the article
}

(c) 2012 Kumar et al; licensee BioMed Central Ltd. This is an Open Access article distributed under the terms of the Creative Commons Attribution License (http://creativecommons.org/licenses/by/2.0), which permits unrestricted use, distribution, and reproduction in any medium, provided the original work is properly cited. 